\title{
Implementation of Values on Family Company Succession in Bali Province, Indonesia
}

\author{
Luh Kadek Budi Martini ${ }^{1}$, Ida Bagus Raka Suardana ${ }^{2} \&$ Ngakan Ketut Acwin Dwijendra $^{3}$ \\ ${ }^{1}$ Department of Management, University of Mahasaraswati, Bali, Indonesia \\ ${ }^{2}$ Department of Management, University of Pendidikan Nasional, Bali, Indonesia \\ ${ }^{3}$ Department of Architecture, University of Udayana, Bali, Indonesia \\ Correspondence: Ngakan Ketut Acwin Dwijendra, Department of Architecture, University of Udayana, Bali, \\ Indonesia. Tel: 62-3-6170-3385. E-mail: acwin@unud.ac.id
}

Received: May 18, 2017

doi:10.5539/jsd.v10n4p75
Accepted: July 12, $2017 \quad$ Online Published: July 30, 2017

URL: https://doi.org/10.5539/jsd.v10n4p75

\begin{abstract}
The main purpose of the research is to investigate the implementation of values on family company successions in Bali. This descriptive research was conducted in family business in Bali which have done successions to, at least, their second generation. The data was analyzed qualitatively and quantitatively by using Likert scale. Meanwhile, to discover the implementation of values towards successors' performance, PLS (Partial Least Square) analysis was carried out. The research elaborates that (1) values are positive and significant effect on the characteristics of successor, (2) values did not affect the succession planning, (3) strong values which were emphasized by the owners did not affect the succession planning, (4) values did not affect the successors' performance, and (5) values which were transferred by predecessors did not have any impacts on the successors' performance. The strongest indicator of values to enhance the performance of successors was innovation.
\end{abstract}

Keywords: family company, business, performance, succession, successor, innovation, values

\section{Introduction}

The family values of the owners of the company greatly influence the corporate culture of a family company (Soedibyo, 2007), so the background of the owner, including ethnic backgrounds also often gives values to the corporate culture mediated by the value that the owner believes (Susanto \& Sujanto, 2008). The values that exist within a company are one of the key factors that is a "family effect", a term used by Dyer (1988) when referring to the impact of the family on performance. He said the values (values) that exist in the family of the company owner is one of the factors that affect the performance of the manager. In the meantime, Miller \& Le Breton-Miller (2005) identifies that the values that come from the founder or the owner of the company are an incentive for employees as an absolute necessity to make the family business live longer, and transfer values are important for the successor to follow what the founder wants.

The study of La Porta et al. (1999) does indicate that family habits affect the performance of company leaders depends on the level of transparency and regulation applied including the planning of succession in it. On the other hand, Gibson et al. (2008) states that systems that penetrate the values, beliefs, and norms that exist in each organization can encourage or reduce the effectiveness of an organization.

Much research has been done about the success of the succession of family firms, but still little to do with the values adopted by the family of the company owners. Family values in a business organization are recognized as strengths in integrating structures, processes and strategies to achieve maximum performance.

Sulistyo (2012) stated that the presence of a well-packaged value system proved to make the organization character and able to show its existence, thus fortifying the company from various crises. Dyer (1998) stated that values are one of the key factors in family impact on managers' performance, as well as Soedibyo (2007) stated that the family values of the owner of the company greatly influence the culture of a family company, which ultimately can make the company live and thrive.

The values, norms and attitudes prevailing within the company from the organizational culture determine the spirit of the family, while the value of family members expresses the creation of a common goal for employees 
and helps to establish a sense of identification and commitment (Susanto, 2008). In a family company that has been running continuously, most employees have a feeling as part of the family, which in turn will create an atmosphere more concerned about the company. Because it is relatively un-bureaucratic, then employee access to senior management is easier and decision-making is faster and more effective (Susanto, 2008).

For example, Sid Lowe's account in describing Overseas Chinese Family Business (OCFB) in Hong Kong, is a cultural hybridization between western and eastern traditionalists (Susanto, 2008). Hybridization of the values of both cultures is characteristic and also one of the superior values of the OCFB culture, which is absorbed from the values and culture of local communities. As a result, it is easier to adapt and develop business in the cultural context in which the company is located.

These values also appear in Chinese Family-owned Enterprise (CFEs) in Singapore that succeed in facing the economic crisis and then rise up to become the driving force of the economy. Admittedly, some characteristics of CFEs are not all considered suitable for modern management. Among them is the lack of separation between ownership and supervision, the existence of nepotism, conservative management, distrust of non-family members, high degree of authoritarianism, based on thrift and hard work, the application of patrilinear path, and based on ethical Chinese business, especially Xinyong (mutual trust). According Fukuyama (2005), some characteristics of this family can hamper the growth of Chinese family business. Similarly Redding (2012: 7-10) states that the Chinese family business forms contain an obstacle to growth. In fact, many Chinese family businesses still exist, so their opinions seem pessimistic.

The development and continuity of Chinese Family Enterprises (CFEs) in Singapore is primarily the result of successful leadership, supervision and management transition from first generation family members to second generation family members, and in other cases to third generation. These second-generation members, professionally trained and open to new management theories are incorporated into Chinese cultural values, such as sparing and simple, persistent, and modifying them into the world of work within a rapidly changing modern context, guided by the values and professional standards of the management example shown by professional managers not family.

In addition, the second generation of family members remains vigorous to maintain the entrepreneurial function within the company, also able to change traditional Chinese values that have no belief in non-family members and undermine distrust of administrative responsibility. Giving responsibility is given to professional managers who are not trained and have capabilities.

Some researchers recognize that the founder exerts a great influence on culture, values and performance during and after the term of office and the particularity of the family business in terms of values is also influenced by the role of the founder (Sharma, 2004). The values of the owner's family are very influential to the family corporate culture. Thus, the background of the owner is crucial. Ethnic backgrounds also often give the corporate culture a color that is reinforced by the value that the owner believes in making leadership change plans within the family company (Susanto \& Sujanto, 2008).

The values that exist within the company are one of the key factors that are "family effects," a term used by Dyer (1988) when referring to the impact of the family on the performance of the manager. Dyer (1988) highlights that family values contribute to high performance, in terms of facilitating lower agency costs due to deep beliefs and shared values between family members, although he also sees that in some cases values Family can encourage nepotism.

A number of other studies that examine family companies show that performance in family firms is influenced by good succession planning. As revealed by Miller and Le Breton-Miller (2005), that a good business succession is a valid indicator of business performance. In times of displacement family business leadership will occur smoothly if successor (substitute) has been prepared better. This is done by preparing successors with friendly (affable) and included in the process of succession planning including the process of transfer of wealth and property rights and the things that have the potential to bring wealth (wealth-transfer).

Family values and traditions have a profound effect on the successor as the company will make business decisions. As Stavrou (1998) argues that the complexity in values, traditions and family relationships affecting successors can effectively develop their role in family enterprises. The specificity of the family business in terms of values generally comes from the values of the founder. The researchers acknowledge that the founders exert great influence on culture, values and performance during and after the tenure (Sharma, 2004).

The empirical and theoretical phenomena described earlier, are also experienced by family companies located in Bali. So what matters in this research is: how the influence of values on the characteristics of successors at 
family companies in Bali and how the influence of values on succession planning at family companies in Bali and how the influence of values on the successor's performance at family companies in Bali , So the purpose of this research is; To explain the influence of values on the characteristics of successors at companies in Bali, and to explain the effect of values on succession planning on family enterprises in Bali, and to explain the effect of values on the successor performance of family firms in Bali.

\section{Research Methodhology}

\subsection{Population and Sample}

Population in this research is all family company that moves on textile and weaving industry that enter the category of IKM (small and medium industry) in Bali Province. Determination of population by region of Regency and City that exist in Bali Province, but not based on kind of textile industry and weaving. The population criteria in this study are: (1) family companies that have made a succession (turn of leadership) at least in the second generation; (2) having a business license; and (3) have financial statements (minimum simple financial report)

To determine representative sample sizes, it is assumed that the variables are normally distributed. The sample size is based on the opinions of Chin (1998) and Henseler et al. (2010), distribution of sample data between 40 and 100. Correspondingly, the sample size is calculated based on the formula developed by Slovin (Sevilla, 2007: 67) as follows:

$$
n=\frac{N}{1+N e^{2}}
$$

Description: $\mathrm{n}$ is the number of samples; $\mathrm{N}$ is population size, e is a fault rate that is tolerated at $10 \%$. With population size $=1.756$ and $d=10 \%$, the sample size (n) of 94.6121 is rounded to 100 samples of family enterprises engaged in the textile and weaving industry, and the sample determination is proportional random sampling in nine districts in Bali.

\subsection{Data Analysis}

Data were analyzed using Partial Least Square Path Modeling (PLS-PM). PLS-PM is a component-based SEM-based Structural Equation modeling (SEM) method. This method was introduced by Herman Wold with the name Partial Least Square/PLS (Tanenhaus, 2008). In component-based SEM, model parameter estimation is done iteratively using a certain algorithm. For example, in PLS, the model parameter estimation is performed in two stages: (1) the score of the constants/latent variables is calculated using the heuristic algorithm, and (2) the OLS method is applied to the score formed to estimate the parameters equation

\section{Results and Discussion}

\subsection{The Influence of Values on the Characteristics of Successors}

The results of the study found that values have a positive and significant effect on the characteristics of successors. This result can be interpreted as the stronger the predecessor values, the more successful the successor characteristics necessary for succession (over leadership).

In this study, 3 dimensions have been confirmed with each of the 5 indicators forming the variables of values, namely the personality dimension with indicators of honesty, credibility, compliance with the law, maintaining the honor and vision of top management; dimension of service with quality indicators, crafts, willingness to work hard, service attitude and responsibility; dimension of independence with indicators of flexibility, tolerance to stress, welfare, innovation and autonomy. When viewed from the profile of variable values, then the innovative indicator is most emphasized by the predecessor in running the business, while the characteristics of successors lies in the indicator of willingness to take over. Based on that finding, the findings that say values proved to have a positive and significant effect on the characteristics of successors, it can be interpreted that the stronger the predecessor values of willingness in the form of innovation, the willingness to take over the more necessary for succession.

The findings of this study are in line with what Miller and Le Breton-Miller (2005) have pointed out, that the values of the company's predecessors are a boost for employees as an absolute necessity to make family business sustainable, and the transfer of values is essential for the successors to follow what aspired by the founders. Meanwhile, Stavrou (1998) states that the stronger interaction between parents and children who become the next generation will affect the decisions taken by the child in the future. One of them is family values and traditions have a big influence on the character of the next generation when the child will take business decisions. 
The complexity in values and family relationships affect the characteristics of the successor and will effectively develop his role in the family enterprise. Values are emphasized to successors in order to avoid different values shared by previous generations as founders and characteristics possessed by successors as individuals who continue the family business. If there is no independence from the values emphasized, then the predecessor may be unwilling to give up his or her leadership vigorously.

The results of this study are similar to those expressed by Koiranen (2002), Tapies \& Moya (2012) and Robbins (2007) stating that values derived from the previous founders or managers are the moral principles, standards, Behavioral norms that are part of a culture that determines the extent to which members of an organization including a successor engage in activities to achieve company goals. The same thing is also expressed by Armstrong (2009) and Wood et al. (2001) which emphasizes values is part of organizational culture related to the subjective aspects of a person in understanding what is happening in the organization so as to give effect to the individuals that exist within the organization. Similarly, Davis \& Harveston (1998) who express the values that are part of organizational culture that must be understood, imbued and practiced by members of the organization, so that the pattern becomes the basis of behave in the company.

On the same side, Aronoff and Ward (2000) argue that the power of values in the family business is related to several factors such as: the foundation for corporate culture; provide templates for decision making; the ultimate inspiration for performance; support customers; long-term view; reduce capital costs; challenging conventional thinking; adapt to change; enhance strategic planning; implement the strategy; strategic alliances; recruit and retain employees; and is considered a meaning to work.

The findings of this study are somewhat different from those proposed by Nelton (2006) and Danco (2012) which states that the predecessor predominantly hopes to his assistant to have business experience before taking over the family company. This is supported by the opinion of Barnes (2008) and Correl (1999) which states that the minimum successor has five years experience in another company and at least followed by one promotion in the company, since it means that the successor's ability has been acknowledged outside the company. In addition, Danco (2012) and Lansberg \& Astrachan (1994) stated that the importance of experience and participation in the management of family firms will assist the successor in building relationships with others in the company to understand the culture within the company.

To further explore the hypothesis that values influence the characteristics of successors, and emphasize the importance of innovation as part of the values emphasized by the predecessors, and the keing factors take over the most important role of the successor, the researcher meets 5 (five) entrepreneur as an informant who is a successor of the business of his parents. The five people are Ni Ketut Muliati, SE (51 years), Ni Wayan Sri Sukiti (28 years), Dwi Ayu Purbhaheni Aridhita, SE., SH (28 years old), Gede Suastika Joka Wijaya (30 years) and Ni Nengah Nuriati ( 35 years old). Almost all stated that his parents insisted that successors always innovate in running the business, as well as the transfer of the baton after the desire to take over from the successor.

As told by Ni Ketut Muliati, SE (51 years old) who runs UD Sinar Mulia - Denpasar who stated that his mother told him not to be relaxed in business. At the time this business is submitted, Muliati trusted because it is considered to have a soul of innovation in business. In terms of characteristics of successor, Ni Ketut Muliati, SE (51 years), tells the story is also given full management of this business after he was considered to have a diligent nature and has never been embarrassing family name since childhood, so trusted. In addition, it is known by the parents have a desire to take over and once considered capable enough.

Meanwhile, Ni Wayan Sri Sukiti (28 years) as the manager of UD Sura Kebaya Mesari in Denpasar, ordered by his parents, in order to always innovate in business, in addition it has been considered to have a diligent nature in work. The same thing was also expressed by Dwi Ayu Purbhaheni Aridhita, SE., SH (28 years old), who has 2 years took over the efforts of his parents. Dwi Ayu said that his father who has struggled to raise the business he lives now hopes that Dwi Ayu can maintain a competitive business. Dwi Ayu asked to remain focused and independent. Dwi Ayu also claimed when given the business owned by the family, actually already have another business with a college friend. But the effort has been abandoned because the desire to take over the family business is huge and the family agrees.

Gede Suastika Joka Wijaya (30 years old) who has a family business in Nusa Dua said that given the management of the business with a reservation should not be lazy and must be serious, and not dependent on other parties, because the age of the company is long and already known. Joka Wijaya took over this business from his parents after resigning from his workplace at a private Bank in Denpasar. At that time Joka Wijaya works from morning till night, sometimes even until midnight, so feel the boredom. Finally Joka Wijaya is determined to return home and continue the family business that is now managed. Ni Nengah Nuriati (35 years 
old) who is trusted to manage the family company owned by his parents. Ni Nengah Nuriati is stressed to always try with all his might. Nuriati is trusted to run his organs business after the parents become sulinggih (pastor) and is considered to have a great desire to continue the relay as the manager of the family company.

The results found differences with the theory put forward by King et al. (2001) which states that the indicators of values emphasized to family enterprise successors are more prominent in leadership quality, so family values are emphasized on their leadership skills. A leader who has good quality, is considered capable to lead organization managed. The leadership aspect also becomes one of the aspects in Sharma's (2004) study. The underlying thing is succession of leadership, because of issues regarding the accuracy of the selection of future generations in terms of expertise and experience, the selection of future generations, techniques used in implementing leadership and communication successions that exist between the predecessor and the next generation (Sharma, 2004).

Another important issue that explains the importance of the leadership aspect is the succession of ownership, is the issue of whether ownership in a family enterprise experiences separation between family, business and managerial function in the enterprise journey or still holds the unity between family units, business units and managerial units, Families have an idiosyncratic tendency that can only entrust parties outside of a truly trustworthy family (Sharma, 2004).

The findings found differed from those expressed by Kellermans et al. (2008) which states that individual qualities that refer to the competence of individual successors take precedence when going to take over the company. It is said by Kellermans et al. (2008), in the family business, individual competence is considered to play a dominant and vital role to run a business.

\subsection{The Influence of Values on Succession Planning}

The results found that values have no effect on succession planning, that values positively affect succession planning are not empirically proven. Based on these results it can be stated that although there are values emphasized by the predecessor, but succession planning will not be influenced, and that means that despite the emphasis on innovative values, it has nothing to do with commitment which is the strongest indicator of succession planning.

The findings of this study are incompatible with what was found by Kaslow (2006) in his research which states that the values of the predecessors transferred to his successor are done in incumbent's mentoring, where mentoring activities are one part of preparation or succession planning. In addition to mentoring, successors generally show a better relationship with their predecessors. Miller and Isabelle (2005) argue that in the transitional period of leadership in the family business, it will be smooth if successor (replacement) has been better prepared. Preparations are among others by preparing successors with friendly (affable) and included in the process of succession planning including the process penginda wealth and property rights and the things that have the potential to bring wealth (wealth-transfer).

The results of this study are also not in line with the findings Susanto \& Sujanto (2008) which states that the family values of the predecessor greatly affect the organizational culture of a family company. Therefore the background of the predecessor will be very decisive and ethnic background also often gives color to the organizational culture reinforced by the value believed by the predecessor in conducting leadership succession planning within the family company.

Marpa (2010) in his research stated matters relating to family company succession planning, can not be separated three important factors namely factor from within family, successor factor (successor) and factor from company. He said, research that emphasizes the values that exist in the family will contribute to the process of succession planning and success of leaders in managing the company. Compared to public companies, family firms generally tend to have a long-term view of their business. In public companies often rely on short-term considerations as they relate to business fluctuations. While leaders in the family company certainly have different views and actions than employees, customers, communities, and other important stakeholders, the results of this study are not in line with the statement Brockhaus (2004) which says the most important thing that affects the succession plan is a family attitude, which Is part of the values adopted in a family. Family attitudes that do not support the successor will adversely affect the family business continuity. Therefore, potential successors should have the support, trust and positive attitude of the family.

\subsection{The Effect of Values on the Successor's Performance}

The results show that the values have no effect on the performance of successors, and it proves that empirically the variable values do not affect the performance of successors. Based on these results it can be stated that the 
values transferred by the predecessor, have nothing to do with the successor's performance, or indicate that innovation does not directly affect the achievement of a successor in the family business as measured by the efficiency of the process.

The findings of this study are not in line with those expressed by Dyer (1988), who say the values that exist within the company are one of the key factors that affect performance and underline that family values contribute to high performance, values can facilitate lower agency costs due to deep trust between family members, Dyer (1988), also see that in some cases family values can encourage nepotism. Aronoff and Ward (2000) also stated that values influence performance and support the realization of a company to live longer, which is then corroborated by the research findings Tàpies and Fernández (2010). The first finding of the Tàpies and Fernández (2010) research is the use of a series of values transferred by the founder of the oldest family company in Spain to his successors. The list of values is also used for comparison studies, with three sample countries, namely group one comprised of Spain, France, and Italy, and group two is Finland. The key findings have been that values of quality, honesty and hard work are values that contribute greatly to performance, so companies can live long.

This study is also not in line with that stated by Miller and Le Breton-Miller (2005) and La Porta et al. (1999) who say that values derived from predecessors are an incentive for employees to make a family business perform well that has a long life, and show evidence that family habits affect the performance of company leaders.

Furthermore, this research is also inconsistent with Soedibyo (2007) stated in his dissertation which stated that founder values greatly influenced the corporate culture of a family company, which ultimately can make the company perform well and the company can still live and grow. In addition, the planting of values to the next generation can avoid conflict, because of the clarity of rights and obligations of each of the early, one of which is to apply the concept of unit entity (the distinction between the property itself and the company) must be really clearly understood.

This research is also inconsistent with what Sharma (2004) and Aronoff \& Ward (2000) claim to recognize that the values of the founders of one of them play a major role in performance, and the strength of the values in The family business is related to several factors, among them the peak of inspiration for performance. In the same context but by using different indicators, it shows evidence that founder values have a good effect on performance. Like what Kwek Hong Png did, instilling and passing some values on to his children, Kenny Yap, who is the Managing Director and Chief Executive Officer of Qian Hu Company, as well as his siblings (Susanto, 2015). Kwek Hong Png is the founder of Hong Leong Group, a Singapore-based conglomerate. Those values form the current Qian Hu culture. These values include integrity, perseverance, loyalty, mutual trust, mutual respect, teamwork, and family unity. These values are not only inherited from the senior generation or the founder to the younger generation, but also to non-family employees.

There is another story of Andrew Tan of Alliance Global Group Inc. (AGI), a Filipino conglomerate (Susanto, 2015). He teaches his son, Kevin, to have a sense of compassion, patience, perseverance. Creativity, generosity, and thanking others. Kevin says that his father taught him not to take shortcuts. If you want to be successful, you should always innovate, because change must be done in the midst of a very tight competition today.

What is done by Kwek Hong Png, Yap Tik Huay, and Andrew Tan is usually found in family companies that are in line with the results of this research. The senior generation inculcates and passes on the values to the next generation. It is believed that if successive generations are consistent with these values, family sustainability can be more assured. Because these values have been tested for reliability. These values become family pride and are inherent in the company as a culture that guides the behavior of not only family members but employees from outside the family, including professional managers.

However, the planting and inheritance of these values to future generations should be done with caution, as family firms must anticipate and deal with rapid environmental changes (Susanto, 2015). Not all family values are conducive to the performance, competitiveness, and sustainability of the company. What was originally thought to be fair, may then become a barrier to the progress of the company. To that end, the family company is obliged to sort and select relevant values that are retained, the values that must be adapted to the appropriate context, and the values that should be abandoned as it will hamper the development of the company. In addition, as the company grows, there is also a new value that needs to be developed. Values such as integrity, honesty, persistence, hard work, creativity, long-term orientation, and generosity are certainly required to be maintained. These are the universal values that bring human beings and organizations into glory and prosperity, no exception for family enterprises. The good news is that many of its predecessors in family companies are conscious and striving for future generations to live and apply these values as future generations lead the company. 


\section{Conclusion}

Based on the results of the study and discussion can be concluded: (1) the values have a positive and significant effect on the characteristics of successor, (2) the values do not affect the succession planning, (3) the strong values emphasized by the owners have no effect on succession planning (4) the values have no effect on the performance of successors, and (5) the values transferred by the predecessor, have no impact on the successor's performance. The strongest indicator of values to improve the successor's performance is innovation.

\section{References}

Aronoff, C. E., \& Ward, J. L. (1995). Family-owned businesses: a thing of the past or a model of the future. Family Business Review, 8(2), 121-130. https://doi.org/10.1111/j.1741-6248.1995.00121.x

Barnes, L. B., \& Herson., S. A. (2014). Transferring power in the family business. Harvard Business Review, (54), 377-392.

Brockhaus, R. H. (2004). Family business succession: suggestions for future research. Family Business Review, (17), 165-17. https://doi.org/10.1111/j.1741-6248.2004.00011.x

Chin, W. W. (1998). The partial least squares approach for structural equation modeling. In G. A. Marcoulides (Ed.), Modern Methods for Business Research. London: Lawrence Erlbaum Associates.

Correl, R. W. (1989). Facing up to moving forward: a third generation successor reflections. Family Business Review, 2(1), 17-29. https://doi.org/10.1111/j.1741-6248.1989.00017.x

Danco, L. (2012). Beyond Survival: A Guide For The Business Owner And His Family. Cleveland: OH University Press.

Dyer, Jr. W. G. (1988). Culture and continuity in family firms. Family Business Review, 1(1), 18-23. https://doi.org/10.1111/j.1741-6248.1988.00037.x

Fukuyama, F. (2005). Guncangan Besar: Kodrat Manusia dan Tata Sosial Baru. Jakarta: PT. Gramedia Pustaka Utama

Gibson, J. L., Ivancevich, J. M., Donnelly, Jr. J. H., \& Konopaske, R. (2008). Organizations (Behavior, Structure and Processes) (13th ed.). New York: McGraw Hill Inc.

Kaslow, F. W. (2006). Handbook of Family Business and Family Business Consultation: a Global Perspective. Birmingham: International Business Press.

Kellermans, F. W., Kimberly, A., Eddleston, B. T., \& Pearson, A. (2008). An exploratory study of family member characteristics and involvement: Entrepreneurial Behavior in the Family Firm. Family Business Review, XXI(1), 1-14. https://doi.org/10.1111/j.1741-6248.2007.00107.x

King, S. W., Solomon, G. T., Lloyd, W., \& Fernald, Jr. (2001). Issues in growing a family business: a strategic human resource model. Journal of Small Business Management, 39(1), 3-13. https://doi.org/10.1111/0447-2778.00002

Koiranen, M. (2002). Over 100 years of age but still entrepreneurially active in business: exploring the values and family characteristics of old Finnish family firms. Family Business Review, 15(3), 175-88. https://doi.org/10.1111/j.1741-6248.2002.00175.x

La Porta, R. F., Lopez-De-Silanes, \& Shleifer, A. (1999). Corporate ownership around the world. Journal of Finance, 54(2), 471-517. https://doi.org/10.1111/0022-1082.00115

Lansberg, I., \& Astrachan, J. H. (1994). Influence of family relationship on succession planning and training: the importance of mediating factors. Family Business Review, 7(1), 1-76. https://doi.org/10.1111/j.1741-6248.1994.00039.x

Miller, D., \& Le Breton-Miller. (2005). Managing for the long run: lessons in competitive advantage from great family businesses. Boston: Harvard Business School Press

Robbins, S. P., \& Judge, T. A. (2007). Organizational Behavior. New Jersey: Pearson International Edition.

Sharma, P. (2004). An overview of family business studies: current status and directions for the future. Family Business Review, XVII(1), 1-33. https://doi.org/10.1111/j.1741-6248.2004.00001.x

Soedibyo, M. (2007). Kajian terhadap suksesi kepemimpinan puncak (CEO) perusahaan keluarga Indonesia menurut perspektif penerus. Disertasi. Program Pasca Sarjana, Universitas Indonesia, Jakarta.

Stavrou, E. T. (1998). A four factor model: a guide to planning next generation involvement in the family firm. 
Family Business Review, XI(2), 135-142. https://doi.org/10.1111/j.1741-6248.1998.00135.x

Sulistyo, C. B. (2013). "Values", Sumber Kekuatan Perusahan. Harian Kompas edisi Minggu 12 Mei 2013, Jakarta.

Susanto, A. B., \& Sujanto, F. X. (2008). Corporate Culture and Organization Culture. Jakarta: The Jakarta Consulting Group.

Susanto, A. B., Susanto, P., Wijanarko, H., \& Mertosono, S. (2007). The Jakarta Consulting Group on Family Business. Jakarta: The Jakarta Consulting Group.

Susanto, A. B., Susanto, P., Wijanarko, H., \& Mertosono, S. (2008). A Strategic Management Approach Corporate Culture \& Organization Culture. Jakarta: Divisi Penerbitan The Jakarta Consulting Group.

Tapies, J., \& Moya, M. F. (2012). Values and longevity in family business: evidence from a cross-cultural analysis. Journal of Family Business Management, 2(2), 130-146. https://doi.org/10.1108/20436231211261871

\section{Copyrights}

Copyright for this article is retained by the author(s), with first publication rights granted to the journal.

This is an open-access article distributed under the terms and conditions of the Creative Commons Attribution license (http://creativecommons.org/licenses/by/4.0/). 